\title{
Foreign Direct Investment In Karnataka:A Critical Analysis From 1991-2015
}

\author{
Malleshappa Kumbar* Prof.Vasudev Sedam.H** \\ Department of Studies \& Research in EconomicsGulbarga University, KALABURAGI-585106 (India)
}

\begin{abstract}
In the last twenty five years of economic liberalization foreign direct investment has assumed immense importance in policy frameworks and academic discourses around the world. The total inflow of FDI to India in the last 25 years stands at Rs.21, 35,313.47 crs.Within India; Karnataka is one of the leading destinations for FDI inflows. Karnataka being a reform oriented state has taken several policy initiatives right from 1991 to attract FDI. This has resulted in the rapid growth of FDI to Karnataka. In 2015 the cumulativeFDI inflows to Karnataka stood at Rs. 1, 73,839.17crs thereby making Karnataka as the third largest state attracting FDI in the country. In this context the present paper aims at making a critical analysis of FDI inflows to Karnataka from 1991 to 2015 which will help in the formulation of appropriate policy measures to attract more FDI to the state.
\end{abstract}

Key words: Foreign Direct Investment, Trends, Sectoral distribution, Country wise source,policy suggestions

\section{INTRODUCTION:}

In the last twenty five years of economic liberalization foreign direct investment has assumed immense importance in policy frameworks and academic discourses around the world. The main reason behind this is spread of globalization accompanied by manifold increase in the global FDI flows (US $\$ 158.94$ billion in 1991 to US $\$ 1700$ trillion in 2015).India being the embracer of globalization in 1991 has now turned into a major destination of FDI inflows. According to FDI intelligence's 'The FDI Report 2016' total inflow of FDI to India in 2015 was to the tune of US $\$ 63,000$ million. The total inflow of FDI to India in the last 25 years stands at Rs.21, 35,313.47 crs. Within India, Karnataka is one of the leading destination for FDI inflows. Karnataka being a reform oriented state has taken several policy initiatives right from 1991 to attract FDI.The policy objectives of Karnataka government were driven by firstly, FDI is a source of financial and non-financial (e.g. transfer of technology and managerial skills etc) capital for production of goods and services. Secondly, private FDI is a source of financing investment through non-public debt instrument as well as through public-private partnership programmes and thirdly, FDI is a source of accessing global markets and earning precious foreign exchange (M.R.Narayana). This has resulted in the rapid growth of FDI to Karnataka. In 2015 the cumulativeFDI inflows to Karnataka stood at Rs. $1,73,839.17$ crs thereby making Karnataka as the third largest state attracting FDI in the country. In this context the present paper aims at making a critical analysis of FDI inflows to Karnataka from 1991 to 2015 which will help in the formulation of appropriate policy measures to attract more FDI to the state. The paper has been organized into 3 sections. Section 1 is introductory, which lays basis for the study, overview of literature and objectives of the study. Section 2, describes the database and methodology adopted and in section 3, the critical analysis of FDI inflows to Karnataka has been presented.

\section{REVIEW OF LITERATURE:}

FDI being the prominent issue in the last 25 years, large numbers of studies have been carried out pertaining to the diverse aspects of FDI both at national and international level. However, due to the nonavailability of systemic data at regional level; very few studies have been carried relating to FDI inflows to states. Some of the important studies that are reviewed here are Bajpai and Sachs (2000) in their study 'Foreign Direct Investment in India: issues and problems' found that FDI in India has moved to the reform oriented states "fast moving reformers have tended to attract higher investments, both from foreign and domestic investors". Padhi,Satyaprasad (2002) notes that the initial level of manufacturing influenced the location of FDI inflows in India.Therefore,the states with good infrastructure base have succeeded in attracting more FDI than their counterparts. Morris (2004) on the other hand states that FDI in India has concentrated in the states with largest and best cities and attributed the modest FDI in Gujarat to its inability to develop a city like Bangaluru.Based on the examination of states wise approvals of FDI during 1991-2001 Singh and Srinivasan (2004) concludes that variations in FDI across states could be influenced by specific policy initiatives and narrowly focused government investments in infrastructure. By studying the new projects that 
were implemented or were under implementation during 1992 to early 1998 Chakravorty (2002) concludes that FDI preferred the coastal and metropolitan districts.Goldar,Bishwanath (2007) in his paper "Location of plants of foreign companies in India" opines that by and large the same set of factors influenced the location decisions of plants of local companies as that of foreign companies.Nunnenkamp and Stracke's(2007) study finds significant positive correlation of FDI with percapita income, population density,percapita bank deposits, telephone density, level of education and percapita net value added in manufacturing.However,Agarwal (2005) was of the opinion that rigid labour markets in Indian states has acted as a obstacle in the flow of FDI.Lall and Mengistae's (2005) study found that the local business environment had significant bearing on location decisions. Ramachandran and Goebel (2002) in their study points that Tamilnadu has emerged as one of the most favoured investment destination in India on account of number a advantages viz. strong and stable government with proactive policies, investor friendly and transparent decision making process, sound diversified industrial infrastructure ,comfortable power situation, abundant availability of skilled manpower etc.Mukherjee,Atri (2011) in her paper "Regional inequality in FDI flows to India: the problems and prospects "concludes that the growth of FDI flows to the country has been accompanied by strong regional concentration thereby depriving a large number of Indian states from the benefits of a liberalised FDI regime. Her analysis reveals that market size, agglomeration effects and size of manufacturing and services base in a state have significant positive influence on FDI flows. Thus, all these studies highlight the factors influencing the location of FDI in few states of India. State specific studies making critical analysis of FDI within the states are very scarce. In respect of Karnataka state the same holds true. The first known study on FDI inflows to Karnataka was carried by Prof.M.R.Narayana(2006) in his study 'Inflow of FDI into Karnataka: Patterns, performance and implications' throws light on the policy initiatives of Government of Karnataka to attract FDI, trends for the period of 1991 to 2005 and implications of FDI on GSDP of the state and capital formation. Since then notable studies have not been carried with regard to the FDI inflows to Karnataka .Dr.N.K.Sathyapal Sharma and Krishna, B.S (2013) in their study "Foreign Direct Investment Environment in Karnataka" enlists factors favourable for attracting FDI into Karnataka.According to the authors, the investor friendly policies of state government,favourable physical and social infrastructure are the important factors that have played major role in attracting FDI to Karnataka. Thus, though lot of FDI has flown to India in the post liberalization period and states are the destinations of these inflows little attempts have been made to make critical analysis of FDI inflows to states. This study attempts to fill this gap by making critical analysis of FDI inflows to Karnataka which is one of the front runner states in attracting FDI in India.

The main objectives of the paper are

\section{OBJECTIVES:}

1. To study the FDI trends to Karnataka in the last 25 years

2. To analyse the sectoral distribution of FDI in the state

3. To study the country wise source of FDI inflows to Karnataka

4. To make suitable policy suggestions

\section{HYPOTHESES OF THE STUDY:}

The study keeps following hypotheses for analysis

1. There is an unsteady growth in FDI inflows to Karnataka.

2. The pattern of FDI in terms of country, sector has undergone significant change over the period of time.

IV. DATABASE AND METHODOLOGY:

FDI being a recent phenomenon, systemic data on FDI with regard to states is very scant. The only source of data available are RBI,CMIE and Karnataka Udyog Mitra(KUM).This study has been carried based on the data available from these 3 sources. The time period taken for analysis is from 1991 to 2015 i.e. 25 years of liberalization so that comprehensive and meaningful inferences can be derived. Simple tabular form, percentile, graph and Pie charts have been used to analyse and present data effectively.

\section{CRITICAL ANALYSIS OF FDI INFLOWS TO KARNATAKA FROM 1991 TO 2015:}

\section{A) Trends of FDI inflows to Karnataka:}

Karnataka being one of the modestly developed and pro-reform oriented states in the country has initiated several policy measures to attract FDI right from the beginning of liberalization era. In 1992 to itself Government of Karnataka established a single window agency called Karnataka Udyog Mitra to attract both domestic and foreign investment to the state. As a result today Karnataka has emerged as an important destination for FDI inflows. Trends of FDI inflows to Karnataka in the past 25 years are presented in the following table. 
Table-1Trends in FDI inflows to Karnataka-1991 to 2015

\begin{tabular}{|c|c|c|}
\hline YEAR & $\begin{array}{l}\text { FDI inflows } \\
\text { ( Rs.Crores) }\end{array}$ & $\begin{array}{c}\text { Annual Growth of } \\
\text { FDI inflows }(\%)\end{array}$ \\
\hline 1991-92 & - & - \\
\hline $1992-93$ & - & - \\
\hline 1993-94 & 325.66 & 434.20 \\
\hline 1994-95 & 924.20 & 183.79 \\
\hline $1995-96$ & 2263.13 & 144.88 \\
\hline 1996-97 & 3137.53 & 38.64 \\
\hline $1997-98$ & 6915.11 & 120.40 \\
\hline 1998-99 & 623.22 & -90.99 \\
\hline $1999-2000$ & 1230.31 & 97.41 \\
\hline $2000-2001$ & 4954.64 & 302.71 \\
\hline 2001-2002 & 805.44 & -83.74 \\
\hline $2002-2003$ & 2284.00 & 183.57 \\
\hline $2003-2004$ & 447.00 & -80.43 \\
\hline 2004-2005 & 6456.13 & 1344.32 \\
\hline $2005-2006$ & 9275.33 & 43.66 \\
\hline $2006-2007$ & 14089.75 & 51.90 \\
\hline $2007-2008$ & 23742.71 & 68.51 \\
\hline $2008-2009$ & 29789.25 & 25.46 \\
\hline $2009-2010$ & 6133 & -79.41 \\
\hline $2010-2011$ & 7235 & 17.96 \\
\hline $2011-2012$ & 5553 & -23.24 \\
\hline $2012-2013$ & 11422 & 81.11 \\
\hline 2013-2014 & 21255 & 86.08 \\
\hline $2014-2015$ & 21883 & 2.95 \\
\hline $2015-2016$ & 17005 & - \\
\hline $\begin{array}{l}\text { Cumulative } \\
\text { inflows }\end{array}$ & $173839.17 \mathrm{crs}$ & $(7.02 \%)$ \\
\hline
\end{tabular}

Source: Compiled from FDI Fact Sheet and Synopsis of FDI Karnataka, RBI various issues.

The analysis of trends of FDI inflows to Karnataka state shows high annual variations in size and growth. The amount of FDI inflows was about RS.325.66 crs in 1993-94 it increased to Rs.6915.11 crs in 1997 88 , but very next year declined to Rs.623.22 crs.Therby recording negative growth of $-90.99 \%$.Again in the year 1999-00 and 2000-2001 FDI inflows increased to RS.1230.31 crs and RS.4,954.64crs respectively.But,in 20012002 FDI inflows decreased to $805.44 \mathrm{crs}$.In the decade between 2001 to 2010 amount of FDI inflows saw substantial increase except in the year 2003-3004 which recorded negative growth. The year 2008-09 recorded highest FDI inflows amounting to Rs.29, 789.25 crs.But,in the next four years there is a considerable decline in the inflow of inflow of FDI to the state. This may be attributed to slow face of liberalization experienced by the country. However, since 2013-14 FDI inflows to Karnataka shows considerable increase and in 2013-2014 FDI inflows stood at Rs.21, 883 and in 2015-16 Rs.17, 005crs respectively. The cumulative FDI inflows to Karnataka in the last 25 years stands at Rs.1, 73,839.17crs and Karnataka is the 3 largest recipient of FDI in the country over the years.

Fig: 1.Trends in FDI inflows to Karnataka-1991 to 2015

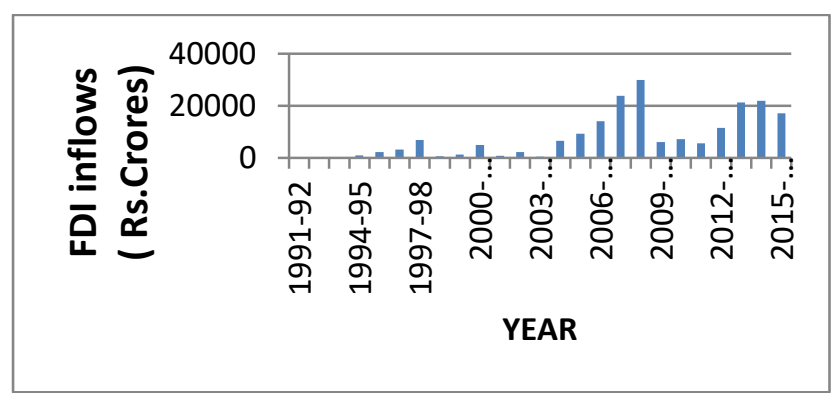


A look at the annual growth also reveals that there is a considerable variation in the growth of FDI to Karnataka over the years. In 1993-94 growth of FDI was 434.20 percent but it declined to -90.99 percent in 1998.99.Again in the year 1999-2000 the annual growth of FDI saw positive growth with 97.41 percent but by the year 2003-04 the growth reached -80.43 percent similar trends can be seen throughout the years from 2004-05 onwards. Thus, the trends of FDI inflows reveal that there is no steady growth of FDI inflows to Karnataka over the years rather there are several ups and downs in the inflows in last 25 years.

Fig: 2.Annual Growth of FDI inflows to Karnataka-1991-92 to 2015-16(in Percentage)

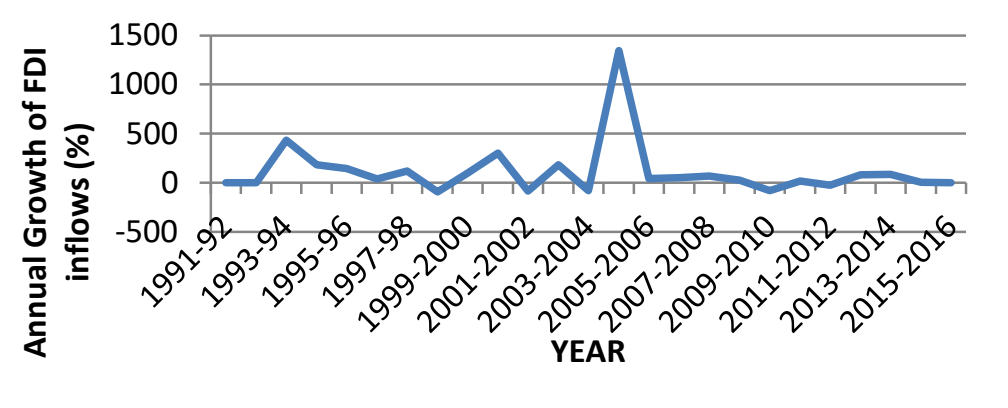

B) Sectoral Distribution of FDI inflows:

The sectoral distribution of FDI in Karnataka for the period 1991 to 2015 is presented in table 2.

Table-2 Sectoral Distribution of FDI in Karnataka (1991 to 2015)

\begin{tabular}{|c|c|c|c|c|c|c|c|c|}
\hline \multicolumn{3}{|c|}{$1991-2008$} & \multicolumn{3}{|c|}{$2000-2008$} & \multicolumn{3}{|c|}{$2000-2015$} \\
\hline $\begin{array}{l}\text { Ra } \\
\text { nk }\end{array}$ & Sector & $\begin{array}{c}\text { FDI } \\
\text { (Rs.Cr } \\
\text { ores) }\end{array}$ & $\begin{array}{c}\text { Ran } \\
\mathrm{k}\end{array}$ & Sector & $\begin{array}{c}\text { FDI } \\
\text { (Rs.Cro } \\
\text { res) }\end{array}$ & $\begin{array}{l}\mathrm{Ra} \\
\mathrm{nk}\end{array}$ & Sector & $\begin{array}{c}\text { FDI } \\
\text { (Rs.Cr } \\
\text { ores) } \\
\end{array}$ \\
\hline 01 & $\begin{array}{l}\text { Fuels } \\
\text { (power, } \\
\text { oil } \\
\text { refinery) }\end{array}$ & $\begin{array}{l}667.29 \\
(26.28)\end{array}$ & 01 & $\begin{array}{c}\text { Comput } \\
\text { er } \\
\text { softwar } \\
\text { e and } \\
\text { hardwar } \\
\text { e }\end{array}$ & $\begin{array}{l}422.70 \\
(17.69)\end{array}$ & 01 & $\begin{array}{c}\text { Compu } \\
\text { ter \& } \\
\text { softwar } \\
\text { e }\end{array}$ & $\begin{array}{c}18329 . \\
27 \\
(29.27 \\
)\end{array}$ \\
\hline 02 & Service & $\begin{array}{l}580.27 \\
(22.87)\end{array}$ & 02 & $\begin{array}{c}\text { Housin } \\
\text { g \& } \\
\text { Real } \\
\text { estate }\end{array}$ & $\begin{array}{l}280.31 \\
(11.73)\end{array}$ & 02 & $\begin{array}{c}\text { Tradin } \\
\mathrm{g}\end{array}$ & $\begin{array}{c}15087 . \\
84 \\
(13.14 \\
)\end{array}$ \\
\hline 03 & $\begin{array}{c}\text { Transpo } \\
\text { rtation }\end{array}$ & $\begin{array}{l}279.70 \\
(11.02)\end{array}$ & 03 & $\begin{array}{l}\text { Service } \\
\text { s Sector }\end{array}$ & $\begin{array}{l}268.06 \\
(11.22)\end{array}$ & 03 & $\begin{array}{l}\text { Service } \\
\text { sector }\end{array}$ & $\begin{array}{c}12820 . \\
84 \\
(12.56 \\
)\end{array}$ \\
\hline 04 & $\begin{array}{c}\text { Electrica } \\
1 \\
\text { equipme } \\
\text { nts }\end{array}$ & $\begin{array}{c}234.62 \\
(9.24)\end{array}$ & 04 & $\begin{array}{c}\text { Constru } \\
\text { ction } \\
\text { activitie } \\
\text { s }\end{array}$ & $\begin{array}{c}143.79 \\
(143.79 \\
(6.02)\end{array}$ & 04 & $\begin{array}{l}\text { Constr } \\
\text { uction } \\
\text { activiti } \\
\text { es } \\
\end{array}$ & $\begin{array}{c}8357.7 \\
6 \\
(9.26)\end{array}$ \\
\hline 05 & $\begin{array}{c}\text { Ferment } \\
\text { ation }\end{array}$ & $\begin{array}{c}168.76 \\
(6.65)\end{array}$ & 05 & $\begin{array}{c}\text { Teleco } \\
\text { mmunic } \\
\text { ation }\end{array}$ & $\begin{array}{c}120.17 \\
(5.03)\end{array}$ & 05 & $\begin{array}{l}\text { Chemi } \\
\text { cals }\end{array}$ & $\begin{array}{c}3677.9 \\
0 \\
(3.48) \\
\end{array}$ \\
\hline & Total & $\begin{array}{c}19306 . \\
69 \\
(76.04)\end{array}$ & & Total & $\begin{array}{c}12350.5 \\
4 \\
(51.69)\end{array}$ & & Total & $\begin{array}{c}58273 . \\
61 \\
(55.31 \\
)\end{array}$ \\
\hline & $\begin{array}{c}\text { Other } \\
\text { sectors }\end{array}$ & (23.96) & & $\begin{array}{l}\text { Other } \\
\text { sectors }\end{array}$ & $(48.31)$ & & $\begin{array}{l}\text { Other } \\
\text { sectors }\end{array}$ & $\begin{array}{c}(44.69 \\
)\end{array}$ \\
\hline
\end{tabular}

Source: Compiled from FDI synopsis on Karnataka, RBI. various issues \# Figures in parentheses indicates percentages 
Fig: 3.Sectoral Distribution of FDI in Karnataka - 1991 to 2015 (in percentage)
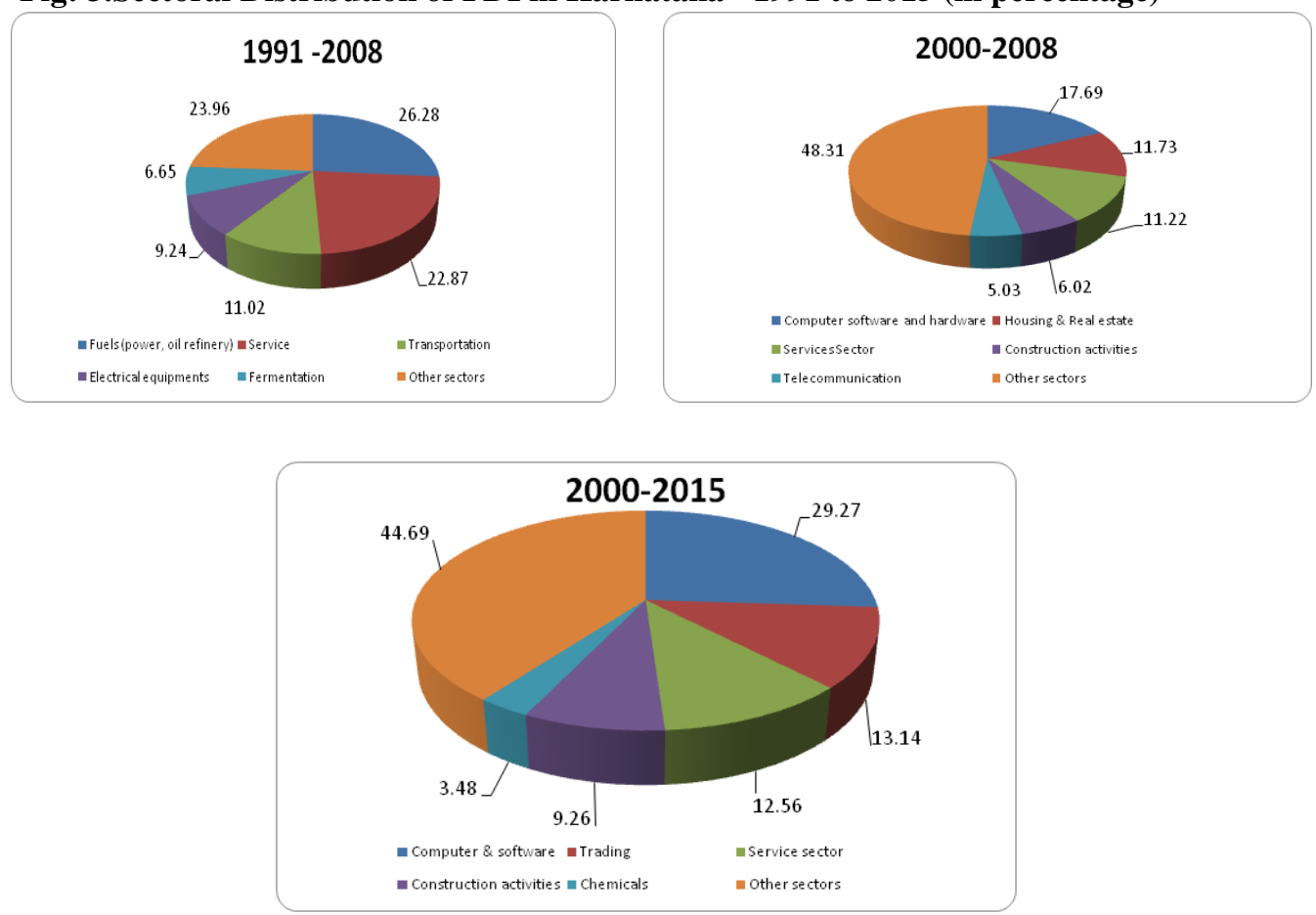

The analysis of sectoral distribution of FDI reveals that during 1991-2008 fuel sector i.e. energy sector received highest FDI of Rs.667.29crores (26.28\%)followed by service sector Rs.580.27crs(22.85\%),transportation sector Rs.279.70crs (11.02\%),electrical equipments Rs.234.62crs (9.24\%) and fermentation Rs.168.76crs (6.65\%). These five sectors topped the FDI inflows between 1991-2008 and cornered total FDI inflows of Rs.19,306.69crs which accounted $76.04 \%$ of total FDI inflows to the state during the period. During the period 2000-08, the trend of FDI distribution changed, computer and software (Rs.422.70 crs) housing and real estate (Rs.280.31crs) service sector (Rs.268.06crs), construction activities (Rs.143.79crs), telecommunication (Rs.120.17crs) topped the FDI inflows to the state. These five activities received total FDI inflows of Rs.12, 350.54crs which accounted for 51.69\% of total FDI inflows during the period. In the period 2000-2015 computer and software activities received FDI of Rs.18,329.27crs, followed by trading Rs.15,087crs,service sector Rs.12,82.84crs,construction activities Rs.8,357.76crs and chemicals Rs.3,677.90crs. The combined FDI inflows to these 5 sectors amounted to Rs.58,273.61crs which accounted for $55.31 \%$ of total FDI inflows to the state during the period. From the above analysis it is clear that in the initial years of liberalization the traditional sectors i.e. fuels, transportation, electrical activities received highest FDI because of existence MNC's already in these activities in the state. But, since 2000 onwards the sunrise sectors viz. computer and software development, housing and real estate, service sector, telecommunication, construction, chemicals and fertilizers activities dominated FDI inflows. This is due to the tremendous growth of information technology sector globally and emergence of Bangalore as the IT \& BT hub in the country. The sectoral distribution of FDI in the state during the period has been depicted in the following Pie chart.

\section{C.Country wise FDI inflows:}

Foreign direct investment is the global inflow of capital in the host country or state. Many countries across the world have invested in India since liberalisation. The country wise inflow of FDI to Karnataka is presented in the following table.

TABLE-3

Top five countries invested in Karnataka - 1991-2015

\begin{tabular}{|c|c|c|c|c|c|c|c|c|}
\hline \multicolumn{3}{|c|}{$1991-2008$} & \multicolumn{3}{c|}{$2000-2008$} & \multicolumn{3}{c|}{$2000-2015$} \\
\hline Rank & Country & $\begin{array}{c}\text { FDI in } \\
\text { Rs.crs }\end{array}$ & Rank & Country & $\begin{array}{c}\text { FDI IN } \\
\text { Rs.crs }\end{array}$ & Rank & Country & $\begin{array}{c}\text { FDI } \\
\text { inrs.crs }\end{array}$ \\
\hline 1 & USA & $\begin{array}{c}3811.16 \\
(15.01)\end{array}$ & 1 & Mauritius & $\begin{array}{c}10382.31 \\
(43.46)\end{array}$ & 1 & Mauritius & $\begin{array}{c}31013.68 \\
(31.46)\end{array}$ \\
\hline 2 & Belgium & $\begin{array}{c}3771.76 \\
(14.86)\end{array}$ & 2 & U.S.A & $\begin{array}{c}2911.84 \\
(12.19)\end{array}$ & 2 & Singapore & $\begin{array}{c}25147.07 \\
(21.19)\end{array}$ \\
\hline
\end{tabular}




\begin{tabular}{|c|c|c|c|c|c|c|c|c|}
\hline 3 & U.K & $\begin{array}{c}2716.19 \\
(10.70)\end{array}$ & 3 & Netherlands & $\begin{array}{c}1674.4 \\
(7.01)\end{array}$ & 3 & U.S.A & $\begin{array}{c}8354.75 \\
(8.72)\end{array}$ \\
\hline 4 & Japan & $\begin{array}{c}2054.68 \\
(8.09)\end{array}$ & 4 & Germany & $\begin{array}{c}1584.31 \\
(6.63)\end{array}$ & 4 & Netherlands & $\begin{array}{c}7756.11 \\
(7.33)\end{array}$ \\
\hline 5 & Mauritius & $\begin{array}{c}2040.14 \\
(8.04)\end{array}$ & 5 & Singapore & $\begin{array}{c}1209.61 \\
(5.06)\end{array}$ & 5 & Japan & $\begin{array}{c}4525.57 \\
(4.21)\end{array}$ \\
\hline TOTAL & & $\begin{array}{c}14393.95 \\
(56.70)\end{array}$ & & & $\begin{array}{c}17762.50 \\
(74.35)\end{array}$ & & & $\begin{array}{c}76797.18 \\
(72.91)\end{array}$ \\
\hline
\end{tabular}

Source: Compiled from FDI synopsis on Karnataka, RBI various issues

\# Figures in parentheses indicates percentage

Fig: 4. Top five countries invested in Karnataka - 1991-2015 (in percentage)
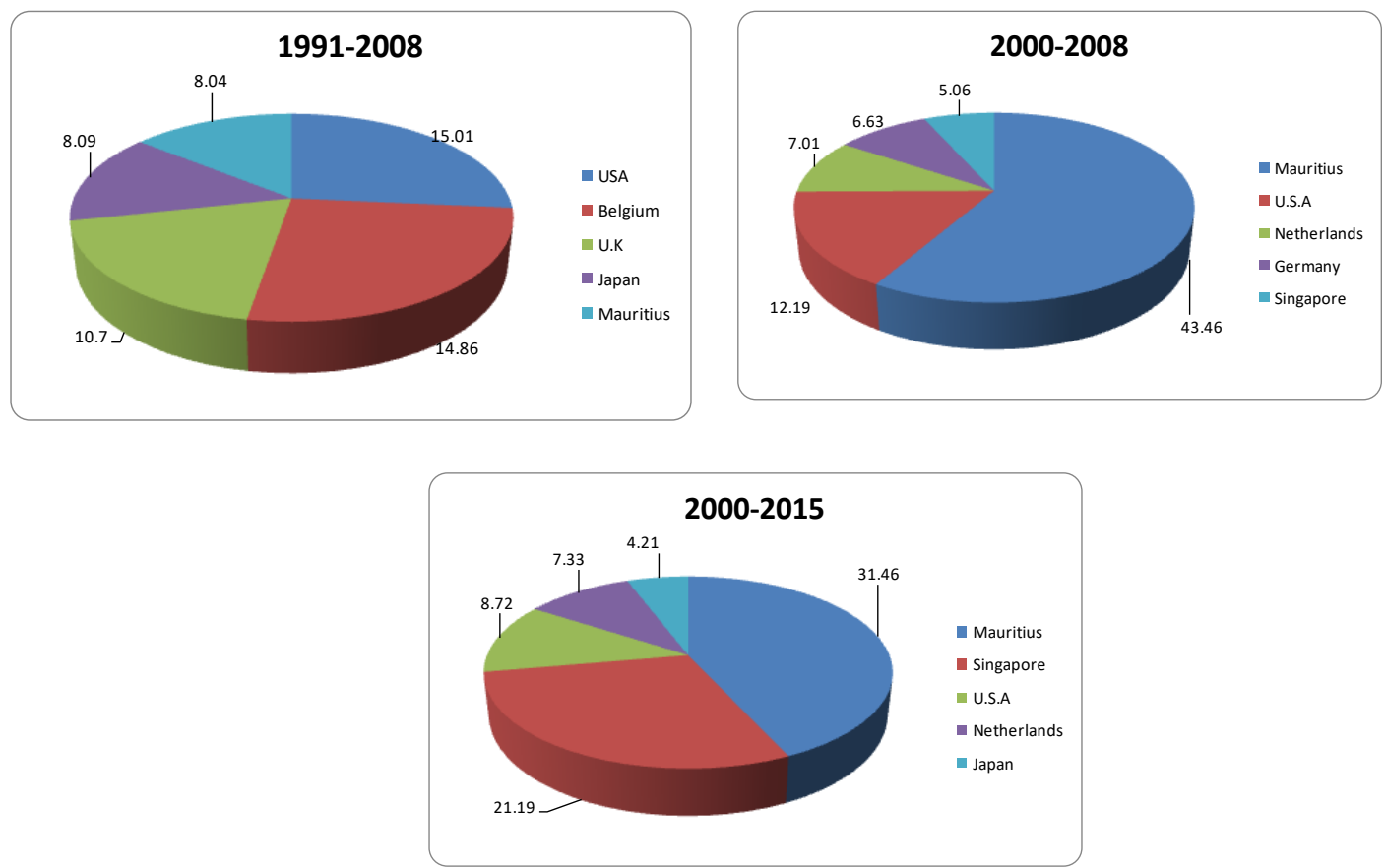

The analysis of country wise FDI inflows to Karnataka reveals that in the initial period of liberalization USA was the top country which invested in Karnataka with total FDI of rs.3,811.16crs (15.01\%) followed by Belgium Rs.3,771.76crs (14.86) U.Krs.2716.19crs (10.7.), Japan Rs.2054.68crs(8.09), and Mauritius Rs.2040.14crs (8.04). The combined investment of these top 5 countries amounted to Rs.14, 393.95crs which is $56.70 \%$ of total FDI investment in Karnataka.But,later in 2000-2008 Mauritius replaced U.S.A as top investor country in Karnataka with total FDI of Rs.31,013.68crs(43.46\%), followed by USA Rs.2911.84 (12.19\%) Netherlands Rs.1, 674.4(7.01\%) Germany Rs.1584.31 (6.63\%) Singapore Rs.1, 209.61 (5.06). USA $(8,354.75 \mathrm{crs})$ Netherlands (Rs.7, 756crs), Japan (Rs.4, 525crs). In the subsequent period also Maruritius remained as the top country investing in Karnataka with total investment of Rs.31, 013.68 (31.46\%) followed by Singapore Rs.25, 147.07 (21.19) USARs.8, 354.75crs (8.72) Netherlands Rs.7, 756crs (7.33) Japan Rs.4, 525crs $4.21 \%$ ) Thus, in the early days of liberalization the traditional sources of foreign capital i.e.U.S.A, U.K, Japan, dominated the foreign investment scenario of $n$ Karnataka. However, in the later period new countries like Singapore, Mauritius, and Netherlands have emerged as major source of FDI inflows to Karnataka.

\section{CONCLUSION:}

The critical analysis FDI inflows to Karnataka leads to the conclusion that Karnataka is one of the leading and predominant state in India as far as FDI inflows is concerened.The total FDI inflows to Karnataka in the last two and half decade amounts to Rs.1, 73,839crs thereby making Karnataka as the third largest state attracting huge amount of FDI.But, the growth rate of FDI to the state is not steady. The sectoral distribution of FDI shows that over the period of time FDI is mostly concentrated in few predominant sectors like computer software, construction, real estate, telecommunication etc. rather than diversifying into other sectors. The country wise FDI inflows reveals the fact that though Mauritius and Singapore have emerged as the top countries investing in Karnataka, the traditional investors USA,Japan ,Germany have remained prominent 
countries investing in Karnatka.This leads to the conclusion that state has failed to diversify the sources of FDI inflows. In the light of above discussion the paper offers following suggestions.

1. Systemic efforts should be made to study the mindset of the foreign investors so, that appropriate policies and programmes could be devised to attract more FDI to the state.

2. Government has to identify the potential areas which could attract FDI rather than showcasing only IT and BT sectors .Agro products processing, horticulture, dairying, mining, tourism, medical facilities, educational training and research etc. are some of the potential areas which could attract FDI.

3. The state government should identify potential countries viz. Middle East, Australia, South East Asia, Canada from which FDI could be attracted.

4. Apart from this the state government has to take measures to improve the infrastructure which is constraining both domestic and foreign investment flows to the state.

5. Last, but not the least steps should be taken to take FDI to the new and backward regions of the state. So that fruits of FDI could percolate down to the remotest part of the state in equitable manner.

\section{REFERENCES:}

[1] Bajpai and Sachs (2000), "Foreign direct Investment in India; Issues and Problems" Development discussion paper no.759, Harvard Institute for International Development, Cambridge.

[2] Chakraborty, C and P.Basu(2002), "Foreign Direct Investment and growth in India: A co-integration approach"Applied Economics,vol.34 pp 1061-1073

[3] Goldar Bishwanath(2007), "Location of plants of foreign companies in India" Institute of Economic Growth, University of Delhi.

[4] Lall, S and Mangistae Taye(2005), "Business environment, clustering and industrial location: Evidence from Indian cities", World Bank Policy Research working paper no.3675.

[5] Morris, S (2004), "A study of the Regional Determinants of FDI in India and the case of Gujarat" working paper no.2004/03/07,Indian Institute of Management, Ahmadabad.

[6] Mukherjee,Atri(2011), "Regional Inequalities in FDI flows to India:The problems and Prospects" Reserve bank of India occasional papers,vol.32.no.2 Monsoon 2011.

[7] Narayan,M.R (2006). "Inflow of FDI into Karnataka: Patterns, performance and implications",Foreign Trade Review,pp3-26.

[8] N.K.Sathyapal Sharma and Krishna,B.S(2013)."Foreign Direct Investment Environment in Karnataka" ,International Journal of Advancements in Research \& Technology,Vol.2,Issue 4 ,April-2013,pp.264-271.

[9] Nunnenkamp and Strack (2007), "Foreign Direct Investment in post-reform India: Likely to work wonder for regional development" Kiel working paper no.1375, Keil institute for the world economy,Kiel(Germany)

[10] Padhi, Satyaprasad (2002), "Attracting Foreign Direct Investment: A regional perspective" Foreign Trade Review, Oct, 1, 2002

[11] Ramachandran, Vijaya and Jeffery,Goebel (2002), "Foreign Direct Investment in Tamilnadu:Review and Comparison across host Cities", Centre for International Development, Harvard university.

[12] Singh and Srinivasan (2005), "Foreign Direct Investment in India: Critical Analysis of FDI from 19912005 " Centre for Civil Society, Research internship Programme, New Delhi.

[13] Suhita Chatterjee, et.al.(2001), "Determinants of inter-state variations in FDI inflows in India, "Eurasian journal of Business and Economics ,2013,69 (11)pp-93-120.

[14] The FDI report 2016, published in FDI intelligence by the Financial Times Ltd. Londan-pp.1

[15] Facts sheet on FDI, RBI various issues.

[16] Synopsis of FDI in Karnataka, RBI various issues. 